\title{
Functional Properties of Yoghurt Fortified with Fruits Pulp
}

\author{
Khoulod Blassy ${ }^{\bowtie}$; Magdy Osman; Amin Gouda and Mervat Hamed \\ Dairy Department, Faculty of Agriculture, Suez Canal University, Ismailia 41522, Egypt
}

Received: $12 / 7 / 2020$

\begin{abstract}
The world interested in food fortification with fruits (e.g. persimmon, mango and guava) that have nutritive and healthy benefits. Therefore, the present study is focused to study the antioxidants properties of yoghurt fortified with fruit pulps. Full fat set yoghurt fortified with different fruit pulps at ratios $(5,10$ and 15\%, w/w) were prepared and stored at $5 \pm 1{ }^{\circ} \mathrm{C}$ for 14 days. Chemical, rheological, total viable lactic acid bacteria and sensory properties were measured when fresh and after 7 and 14 days of storage period. The results indicated that, there were significant differences between plain yoghurt and fruit yoghurt in the total solids (T.S\%), free radical scavenging activity (RSA\%), total phenolic compounds (TPC) and total flavonoid compounds (TFC), which increased with the increase of the fruit pulp ratios. While, $\mathrm{pH}$ value was decreased with the increase of the fruit pulps percentage added and with extended storage period. The yoghurt containing guava pulp had the highest total viable lactic acid bacteria count compared with plain yoghurt and other fruit yoghurt. Sensory evaluation results showed that there were significant $(\mathrm{p}<0.05)$ differences among the yoghurt treatments. The yoghurt containing $10 \%$ mango, $10 \%$ persimmon and 5\% guava were recorded highest scores in full fat yoghurt compared with plain yoghurt and other ratios. The highest apparent viscosity was recorded in yoghurt containing persimmon, mango and guava pulps, respectively. The results of current study demonstrated that addition of fruits to the yoghurt significantly improved the rheological properties, body \& texture and flavour compared with control treatment and support set yoghurt with more bioactive compounds.
\end{abstract}

Keywords: Functional fruit yoghurt, antioxidant scavenging activity, full fat, persimmon, mango and guava

\section{INTRODUCTION}

Yoghurt consumption has increased around the world due to its nutritional value, therapeutic effects and functional properties (Mckinely, 2005). Yoghurt is easily digested, rich source of carbohydrates, protein, fat, vitamins, calcium and phosphorous (Vahedi et al., 2008). It is common to fortify yoghurt with different fruits for enhancing flavour and improve its nutritional as well as sensory properties (Cakmakc1 et al., 2012). Mango, guava, persimmon, pear, cactus, strawberry, blueberry, orange, peach and date fruits or pulps are frequently used in yoghurt production (Arslan and Ozel, 2012; Abdeldaiem and Blassy, 2019). This fruits has important effects in the body defense system against free radical (Manisha et al., 2017). The total solids (pectin and sugars) from the fruits when mixed with yoghurt, causing an increase in its consistency and viscosity therefore, mouth fell is improved (Matter et al., 2016). Fruits may be added to yoghurt formula as pulp, juice, canned or syrup.

Persimmon fruit (Diospyros kaki L.) could be used in yoghurt making as a source of antioxidant and phenolic compounds.It contains high amount of phenolic compounds including polyphenols, carotenoids and also, a good source of fibers, vitamins ( $\mathrm{C}$ and $\mathrm{A}$ ), minerals (iron and calcium) and tannins (Arslan and Bayrakci, 2016; Curi et al., 2017).

Mango fruit (Mangifera indica L.) is one of the most important tropical fruits and a good source of antioxidants especially polyphenols and carotenoids (Nunes et al., 2007). It is an excellent source of vitamin A and flavonoids like alpha-carotene, beta-carotene and beta-cryptoxanthin (Raut et al., 2015; Vazquez-Olivo et al., 2019).

Guava (Psidium guajava) is known as a medical fruit with high nutritive value, it contains a great amount of vitamins $\left(\mathrm{C}, \mathrm{A}, \mathrm{B}_{3}\right.$ and $\left.\mathrm{B}_{4}\right)$. It is an important source of antioxidant due to contain carotenoids like beta-carotene and polyphenols, that can prevent the oxidation of lipids and its play important role in delaying the development of chronic disease such as cardiovascular disease, cancer, inflammatory bowel and Al-Zheimer's disease (Kavas and Kavas, 2016; Parvez et al., 2018).

The present study was focused to study the antioxidant properties of the yoghurts fortified with fruit pulps.

\section{MATERIALS AND METHODS}

\section{Materials}

Milk: Fresh buffalo's milk was obtained from dairy plant, Dairy Department in the Faculty of Agriculture, Suez Canal University, Egypt.

Starter cultures: Direct vat starter (DVS) culture containing Str. thermophilus and Lb.delbrueckii ssp. bulgaricus (YC-X11) was obtained from Chr. Hansen's Laboratories, Denmark. The culture was stored at $18 \pm 1^{\circ} \mathrm{C}$ until used before expired date.

Other materials: Commercial grade crystalline sugar (sucrose), fresh mango, persimmon and guava were obtained from the local market of Ismailia governorate, Egypt.

\section{Methods}

\section{Preparation of fruit pulps}

Fruits (persimmon, mango and guava) were washed, peeled, cut into pieces and seeds were removed. The fruit pieces were blended by mixer (Braun Power Max MX 2000 Blender, Germany) for 5 min to obtain fine paste pulp, heated at $85^{\circ} \mathrm{C}$ for $3 \mathrm{~min}$, cooled to $5 \pm 1^{\circ} \mathrm{C}$, homogenized at $6000 \mathrm{rpm}$ for $5 \mathrm{~min}$ using Ultra Turrax homogenizer (Germany) and kept in polyethylene bags at $5^{\circ} \mathrm{C}$ until used. 


\section{Preparation of full fat fruit yoghurt}

Adjusted buffalo's milk (milk fat 3.7\%, total solids $12.6 \%$ and titratable acidity, $0.17 \%$ ) was used with adding $5 \%$ sugar. It was heated to $85^{\circ} \mathrm{C}$ for $10 \mathrm{~min}$, cooled to $40^{\circ} \mathrm{C}$ and inoculated with $0.03 \%$ yoghurt culture (DVS). Milk was divided into four parts. The first part with no additives used as a control. Each part from previous parts were divided into three equal portions and then $5 \%, 10 \%$ and $15 \%$ of each fruit pulps were added. Then the inoculated milk yoghurt mixes were filled into $120 \mathrm{~g}$ plastic cups and incubated at $42^{\circ} \mathrm{C}$ until $\mathrm{pH}$ reaches to $4.7 \mathrm{pH}$ value $(2-3 \mathrm{~h})$. After complete coagulation, all treatments were stored in the refrigerator at $5 \pm 1{ }^{\circ} \mathrm{C}$ for 14 days and examined when fresh, and after 7 and 14 days of storage period. All treatments were carried out in triplicate.

\section{Chemical analysis of yoghurt}

Yoghurt samples were mixed and analyzed in three replicates for total solids according to the method described in AOAC (2000). The values of $\mathrm{pH}$ were measured using Jenway $\mathrm{pH}$ meter with Jenway spear electrode No: 3505 (Jenway limited, Gransmore green, Felsted, Dunmow, England). The free radical scavenging activity $\%$ of the methanolic extracts was determined by DPPH method described by Caleja et al. (2016). The absorbance of the mixture was measured at $515 \mathrm{~nm}$ by using spectrophotometer (model 20D uv, Milton Roy company, USA). The DPPH solution without extract was used as blank sample. The antioxidant activity was calculated as follows:

DPPH radical-scavenging activity $(\%)=\left[\left(\mathrm{A}_{\text {blank }}\right.\right.$ -

$\left.\left.\mathrm{A}_{\text {sample }}\right) / \mathrm{A}_{\text {blank }}\right]$ x 100

Where, $A$ is the absorbance at $515 \mathrm{~nm}$.

\section{Determination of total phenolic compounds}

Total phenolic compounds were determined in the methanolic extracts by Folin-Ciocalteu assay with slight modifications (Barros et al., 2011). The absorbance was measured at $765 \mathrm{~nm}$ by spectrophotometer (model $6505 \mathrm{uv} / \mathrm{vis}$, JENWAY, UK). A calibration curve of gallic acid $\left(0.00-0.10 \mathrm{mg} \mathrm{ml}^{-1}\right)$ was prepared and total phenolic compounds was determined from the linear regression equation $\left(\mathrm{R}^{2}=\right.$ 0.9986) of the calibration curve. The results were expressed as $\mathrm{mg}$ of gallic acid equivalents per $100 \mathrm{~g}$ of sample.

\section{Determination of total flavonoid compounds}

Total flavonoids content was determined by Barros et al. (2011). The absorbance was measured at
$510 \mathrm{~nm}$ by spectrophotometer (model T80 uv/vis, PG instruments Ltd., USA). A calibration curve of quercetin was prepared and total flavonoids content was determined from the linear regression equation $\left(\mathrm{R}^{2}=\right.$ 0.9976) of the calibration curve. The results were expressed as mg quercetin $100 \mathrm{~g}^{-1}$ of sample.

\section{Apparent viscosity}

Apparent viscosity (mPa.s) was measured at 10 rpm using a Brookfield rotational viscometer model RV 111 at $10^{\circ} \mathrm{C}$ and the Brookfield small sample adapter and $\mathrm{Sc}_{4-14}$ spindle were used (Brookfield Engineering Laboratories Inc., MA, USA) according to Hegedusic et al. (1993).

\section{Lactic acid bacteria count}

Eillker agar medium (Eillker et al., 1956) was used for the enumeration of total viable lactic acid bacteria after incubation (Memmert, Germany) at $37^{\circ} \mathrm{C}$ for 2 days under aerobic condition.

\section{Organoleptic evaluation}

Organoleptic properties for the control and other treatments of fruit yoghurt where evaluated at fresh (1 day) and after 7 and 14 days of storage at $5 \pm 1^{\circ} \mathrm{C}$ by staff members of the dairy department, faculty of Agriculture, Suez Canal University, Egypt as described by IDF (1997). Yoghurt samples were organoleptically scored for flavour (50 points), body \& texture (40 points) and appearance (10 points).

\section{Statistical analysis}

All measurements were done in triplicate and analysis of variance with two factors (treatments and storage time) and conducted by the procedure of General Linear Model (GLM) by using CoStat program (2005) under windows software version 6.311 and least significant difference (LSD) test were employed to determine significant difference at $(\mathrm{p}<0.05)$.

\section{RESULTS AND DISCUSSION}

\section{Chemical composition of fruits pulps:}

Chemical composition of persimmon, mango and guava pulps used for fruit yoghurt manufacturing are shown in Table (1). Data showed that persimmon pulp had the highest T.S and $\mathrm{pH}$ value compared with other fruits. Guava pulp had highest radical scavenging activity \%, total phenolic and total flavonoid compounds compared with persimmon and mango pulps. These results are in agreement with Yaqub et al. (2016) and Parvez et al. (2018).

Table (1): Chemial composition of fruit pulps after preparation

\begin{tabular}{lccc}
\hline Components & Persimmon & Mango & Guava \\
\hline T.S (\%) & 25 & 20 & 14 \\
pH value & 5.2 & 4.53 & 3.7 \\
Radical scavenging activity (\%) & 28.98 & 29.54 & 82.40 \\
$\begin{array}{l}\text { Total phenolic compounds } \\
\left(\mathbf{m g}_{\left.100 \mathbf{g}^{-1}\right)}\right.\end{array}$ & 22.88 & 42.33 & 87.7 \\
$\begin{array}{l}\text { Total flavonoid compounds } \\
\left(\mathbf{m g}_{100 \mathbf{g}^{-1}}\right)\end{array}$ & 2.68 & 9.12 & 10.67 \\
\hline
\end{tabular}




\section{Chemical analysis of fortified yoghurt with fruit pulps \\ Total solids \%}

Total solids content of plain yoghurt recorded the lowest percentage $(14.13 \%)$ compared with other fruit yoghurts (Table 2). Increasing the addition of fruit pulps to yoghurt induced to a parallel significantly $(p<0.05)$ increase in T.S\% of the resultant yoghurt. This increment due to the highest T.S in fruit pulps than that of milk (Ronak et al., 2016). The T.S\% of fruit pulp yoghurt treatments were increased significantly $(p<0.05)$ along the storage period. Similar results were reported by Arslan and Bayrakci (2016).

\section{pH value}

The $\mathrm{pH}$ values of all fruit pulp yoghurt treatments were lower than that of control, addition of fruit pulps decreased significantly $(\mathrm{p}<0.05)$ the $\mathrm{pH}$ values of yoghurt as result of low $\mathrm{pH}$ of fruits (Table 3 ). Tanwar et al. (2014) and Souza et al. (2018) reported similar results. The lowest $\mathrm{pH}$ value was recorded in yoghurt contain $15 \%$ of guava pulp. These results are in agreement with Ziena and Abd-Elhamid (2009). They reported that the decrement in the $\mathrm{pH}$ values of functional yoghurt reflected the high activity of starter.
The $\mathrm{pH}$ of all fruit yoghurt treatments decreased along storage period. This phenomena was due to the growth of lactic acid bacteria and produced lactic acid which was due to the special synergism between Streptococcus sp. and Lactobacillus sp. These results were in agreement with Matter et al. (2016).

\section{Free radical scavenging activity $\%$}

Fruit pulps contain various antioxidant compounds which act against oxidizing agents (Jin et al., 2018). Adding fruit pulps to the yoghurt increased significantly $(\mathrm{p}<0.05)$ the RSA $\%$ of the yoghurt (Table $4)$. The increase proportional with the increase in fruit pulps adding in all treatments. The highest value of RSA \% was recorded in yoghurt contains $15 \%$ of guava pulp. These results are in agreement with Ziena and Abd-Elhamid (2009). During the storage period, the RSA $\%$ was decreased significantly $(p<0.05)$ up to 14 days. Khalil (2013) reported that RSA \% tend to decrease along the storage period, as a result of possible oxidation. Scibisz et al. (2012) attributed the decrease in RSA \% to the interaction with casein or whey protein causing formation of soluble complex which responsible for decreasing RSA \%.

Table (2): Effect of adding persimmon, mango and guava pulps on the total solid \% of yoghurt during storage period

\begin{tabular}{|c|c|c|c|c|}
\hline \multirow{2}{*}{ Treatments } & \multicolumn{3}{|c|}{ Storage period (days) } & \multirow{2}{*}{ Mean } \\
\hline & Fresh & 7 & 14 & \\
\hline $\mathbf{C}$ & $14.13 \pm 0.14$ & $14.45 \pm 0.12$ & $14.60 \pm 0.06$ & $14.38^{g}$ \\
\hline P5 & $14.97 \pm 0.15$ & $15.17 \pm 0.25$ & $15.46 \pm 0.39$ & $15.19^{\mathrm{f}}$ \\
\hline P10 & $16.44 \pm 0.39$ & $17.38 \pm 0.11$ & $17.56 \pm 0.13$ & $17.12^{b}$ \\
\hline P15 & $17.34 \pm 0.11$ & $17.60 \pm 0.05$ & $17.80 \pm 0.10$ & $17.58^{\mathrm{a}}$ \\
\hline M5 & $15.53 \pm 0.16$ & $15.74 \pm 0.17$ & $15.80 \pm 0.01$ & $15.69^{e}$ \\
\hline M10 & $16.60 \pm 0.02$ & $16.79 \pm 0.02$ & $17.85 \pm 0.05$ & $17.07^{b}$ \\
\hline M15 & $17.32 \pm 0.09$ & $17.44 \pm 0.03$ & $17.54 \pm 0.02$ & $17.43^{\mathrm{a}}$ \\
\hline G5 & $14.95 \pm 0.06$ & $15.17 \pm 0.07$ & $15.23 \pm 0.06$ & $15.11^{\mathrm{f}}$ \\
\hline G10 & $15.81 \pm 0.07$ & $15.91 \pm 0.06$ & $16.16 \pm 0.19$ & $15.69^{\mathrm{e}}$ \\
\hline G15 & $16.43 \pm 0.08$ & $16.52 \pm 0.08$ & $16.87 \pm 0.60$ & $16.60^{\mathrm{c}}$ \\
\hline Mean & $15.80^{\mathrm{c}}$ & $16.04^{b}$ & $16.30^{\mathrm{a}}$ & \\
\hline
\end{tabular}


Table (3): Effect of adding persimmon, mango and guava pulps on $\mathrm{pH}$ value of yoghurt during storage period

\begin{tabular}{|c|c|c|c|c|}
\hline \multirow{2}{*}{ Treatments } & \multicolumn{3}{|c|}{ Storage period (days) } & \multirow{2}{*}{ Mean } \\
\hline & Fresh & 7 & 14 & \\
\hline $\mathbf{C}$ & $4.69 \pm 0.14$ & $4.43 \pm 0.10$ & $4.24 \pm 0.36$ & $4.74^{\mathrm{a}}$ \\
\hline P5 & $4.57 \pm 0.06$ & $4.54 \pm 0.02$ & $4.34 \pm 0.23$ & $4.48^{\mathrm{de}}$ \\
\hline P10 & $4.71 \pm 0.15$ & $4.66 \pm 0.14$ & $4.61 \pm 0.02$ & $4.65^{\mathrm{abc}}$ \\
\hline P15 & $4.26 \pm 0.34$ & $4.69 \pm 0.08$ & $4.61 \pm 0.06$ & $4.52^{\mathrm{de}}$ \\
\hline M5 & $4.76 \pm 0.01$ & $4.73 \pm 0.01$ & $4.61 \pm 0.01$ & $4.70^{a b}$ \\
\hline M10 & $4.63 \pm 0.02$ & $4.61 \pm 0.01$ & $4.51 \pm 0.01$ & $4.58^{\mathrm{bcc}}$ \\
\hline M15 & $4.55 \pm 0.01$ & $4.42 \pm 0.01$ & $4.35 \pm 0.02$ & $4.44^{\mathrm{ef}}$ \\
\hline G5 & $4.67 \pm 0.03$ & $4.60 \pm 0.01$ & $4.42 \pm 0.03$ & $4.56^{\mathrm{cde}}$ \\
\hline G10 & $4.45 \pm 0.02$ & $4.33 \pm 0.01$ & $4.21 \pm 0.01$ & $4.32^{f}$ \\
\hline G15 & $4.37 \pm 0.03$ & $4.04 \pm 0.05$ & $3.98 \pm 0.03$ & $4.13^{\mathrm{g}}$ \\
\hline Mean & $4.58^{\mathrm{a}}$ & $4.52^{\mathrm{a}}$ & $4.41^{\mathrm{b}}$ & \\
\hline
\end{tabular}

C: control; P5: persimmon, 5\%; P10: persimmon, 10\%; P15: persimmon, 15\%; M5: mango, 5\%; M10: mango, 10\%; M15: mango, 15\%; G5: guava, 5\%; G10: guava, $10 \%$ and G15: guava, $15 \%$. ${ }^{a}$ Values are means \pm standard deviations of triplicate determinations. Means in the same row with different superscript $(a, b, c \ldots)$ are significantly different $(\mathrm{p}<0.05)$.

Table (4): Effect of adding persimmon, mango and guava pulps on radical scavenging activity \% of yoghurt during storage period

\begin{tabular}{|c|c|c|c|c|}
\hline \multirow{2}{*}{ Treatments } & \multicolumn{3}{|c|}{ Storage period (days) } & \multirow{2}{*}{ Mean } \\
\hline & Fresh & 7 & 14 & \\
\hline $\mathbf{C}$ & $10.25 \pm 0.12$ & $9.57 \pm 0.03$ & $8.89 \pm 0.16$ & $9.57^{\mathrm{g}}$ \\
\hline P5 & $12.27 \pm 1.16$ & $13.60 \pm 0.50$ & $11.30 \pm 0.51$ & $12.38^{\mathrm{i}}$ \\
\hline P10 & $16.54 \pm 1.65$ & $18.29 \pm 1.89$ & $15.85 \pm 1.05$ & $16.89^{\mathrm{d}}$ \\
\hline P15 & $18.86 \pm 1.98$ & $20.95 \pm 1.85$ & $17.60 \pm 2.15$ & $18.46^{\mathrm{c}}$ \\
\hline M5 & $11.86 \pm 0.03$ & $10.89 \pm 0.10$ & $10.58 \pm 0.09$ & $11.19^{h}$ \\
\hline M10 & $13.50 \pm 0.05$ & $13.30 \pm 0.12$ & $12.61 \pm 0.02$ & $13.13^{\mathrm{g}}$ \\
\hline M15 & $15.67 \pm 0.10$ & $15.30 \pm 0.02$ & $14.97 \pm 0.05$ & $15.31^{\mathrm{e}}$ \\
\hline G5 & $14.22 \pm 0.14$ & $14.13 \pm 0.11$ & $13.90 \pm 0.05$ & $14.08^{f}$ \\
\hline G10 & $22.87 \pm 0.07$ & $21.71 \pm 0.21$ & $18.15 \pm 0.05$ & $18.47^{b}$ \\
\hline G15 & $22.87 \pm 0.07$ & $21.71 \pm 0.21$ & $20.14 \pm 0.05$ & $21.57^{\mathrm{a}}$ \\
\hline Mean & $15.15^{\mathrm{a}}$ & $15.28^{\mathrm{a}}$ & $14.11^{\mathrm{b}}$ & \\
\hline
\end{tabular}

C: control; P5: persimmon, 5\%; P10: persimmon, 10\%; P15: persimmon, 15\%; M5: mango, 5\%; M10: mango, 10\%; M15: mango, 15\%; G5: guava, 5\%; G10: guava, $10 \%$ and G15: guava, $15 \%$. ${ }^{a}$ Values are means \pm standard deviations of triplicate determinations. Means in the same row with different superscript $(a, b, c \ldots)$ are significantly different $(p<0.05)$. 


\section{Total phenolic compounds}

Fruit pulps are a good source of antioxidants, especially, polyphenols, carotenoids, dietary fiber and vitamin C (Abbasi et al., 2017). Fortifying yoghurt with fruit pulps increased the TPC, the increment was in parallel with the increase of added fruit pulps ratios. Similar results were reported by El-Batawy et al. (2014). Addition of fruit pulps affect significantly $(\mathrm{p}<0.05)$ the TPC value of all fruit yoghurt treatments compared with control (Table 5). It is clear that addition of guava pulp recorded the highest value $(p<0.05)$ in TPC content of fruit yoghurt at all ratios, due to the high contents of TPC in guava pulp. These results are in agreement with Ismail et al. (2017). Throughout the storage period, the TPC decreased gradually for all fruit yoghurt treatments. The storage period significantly $(\mathrm{p}<0.05)$ affected the TPC of all fruit yoghurt treatments. The decreased in TPC could be attributed to decomposition of some TPC contents. Also, the decrease in TPC may be due to the hydrolysis of polyphenols by LAB to aromatic acids such as phenyl acetic, phenyl propionic and benzoic acids. Phenolic compounds could be divided to subgroups as phenolic acids, flavonoids and tannins (Sagdic et al., 2012). These results were in agreement with El-Kholy (2018).

Table (5): Effect of adding persimmon, mango and guava pulps on total phenolic compounds (mg GAE $\left.100 \mathrm{~g}^{-1}\right)$ of yoghurt during storage period

\begin{tabular}{|c|c|c|c|c|}
\hline \multirow{2}{*}{ Treatments } & \multicolumn{3}{|c|}{ Storage period (days) } & \multirow{2}{*}{ Mean } \\
\hline & Fresh & 7 & 14 & \\
\hline $\mathbf{C}$ & $0.99 \pm 0.01$ & $0.98 \pm 0.01$ & $0.94 \pm 0.01$ & $0.96^{\mathrm{h}}$ \\
\hline P5 & $1.10 \pm 0.02$ & $1.14 \pm 0.03$ & $1.04 \pm 0.03$ & $1.09^{\mathrm{fgh}}$ \\
\hline P10 & $1.26 \pm 0.04$ & $1.32 \pm 0.06$ & $1.22 \pm 0.03$ & $1.26^{\mathrm{ef}}$ \\
\hline P15 & $1.75 \pm 0.09$ & $1.84 \pm 0.06$ & $1.74 \pm 0.01$ & $1.77^{\mathrm{d}}$ \\
\hline M5 & $1.08 \pm 0.05$ & $1.01 \pm 0.01$ & $0.98 \pm 0.01$ & $1.02^{\mathrm{gh}}$ \\
\hline M10 & $1.21 \pm 0.02$ & $1.19 \pm 0.01$ & $1.03 \pm 0.01$ & $1.14^{\text {efg }}$ \\
\hline M15 & $1.37 \pm 0.02$ & $1.33 \pm 0.01$ & $1.21 \pm 0.02$ & $1.30^{\mathrm{e}}$ \\
\hline G5 & $4.72 \pm 0.05$ & $4.55 \pm 0.03$ & $4.35 \pm 0.05$ & $4.53^{c}$ \\
\hline G10 & $8.28 \pm 0.16$ & $7.91 \pm 0.10$ & $7.11 \pm 0.10$ & $7.76^{b}$ \\
\hline G15 & $10.45 \pm 0.14$ & $9.94 \pm 0.04$ & $9.31 \pm 0.05$ & $9.9^{\mathrm{a}}$ \\
\hline Mean & $3.01^{\mathrm{a}}$ & $2.93^{\mathrm{a}}$ & $2.71^{b}$ & \\
\hline
\end{tabular}

C: control; P5: persimmon, 5\%; P10: persimmon, 10\%; P15: persimmon, 15\%; M5: mango, 5\%; M10: mango, 10\%; M15: mango, 15\%; G5: guava, 5\%; G10: guava, $10 \%$ and G15: guava, $15 \%$. ${ }^{a}$ Values are means \pm standard deviations of triplicate determinations. Means in the same row with different superscript $(a, b, c \ldots)$ are significantly different $(p<0.05)$.

\section{Total flavonoid compounds}

Flavonoid is a bioactive phytochemicals found in fruit, vegetables. Fruits are rich sources of antioxidant activity and can help our body to stay healthy. It could be notice that yoghurt fortified with persimmon, mango and guava pulps have higher TFC than control as shown in Table (6). Fortification of yoghurt with guava pulp increased significantly $(p<0.05)$ the TFC, the increment was in parallel with the increase of added pulp ratios. These results are in agreement with Moussa and ElGend (2019). It was clear that the G15 and G10 treatments were recorded the highest TFC contents than control and other treatments. Ismail et al. (2017) stated that peel and pulp of guava fruit presented high levels of flavonoid compounds. Along the storage period, the TFC decreased significantly $(p<0.05)$ for all fruit yoghurt treatments. These results were in agreement with the study of Jin et al. (2018).

\section{Apparent Viscosity}

Viscosity is defined as the resistance of flow. The viscosities of liquid and semi-solid foods have a large impact on their quality characteristics (Karaman et al., 2014). The apparent viscosity of fruit yoghurt increased with the increase of fruit pulp addition compared with control. The higher apparent viscosity was recorded to mango yoghurt treatments than other treatments as shown in Table (7). It may be due to the absorption of water by water soluble fibers in mango (Mahmood et al., 2008). A significant $(\mathrm{p}<0.05)$ differences could be noticed between control and other fruit pulp treatments. Throughout the storage period the apparent viscosity increased significantly $(\mathrm{p}<0.05)$ up to day $7^{\text {th }}$, then a gradually decreased at day $14^{\text {th }}$ for all fruit yoghurt treatments. These results are in agreement with Kavas and Kavas (2016). 
Table (6): Effect of adding persimmon, mango and guava pulps on total flavonoid compounds (mg quecretin $100 \mathrm{~g}^{-1}$ ) of yoghurt during storage period

\begin{tabular}{|c|c|c|c|c|}
\hline \multirow{2}{*}{ Treatments } & \multicolumn{3}{|c|}{ Storage period (days) } & \multirow{2}{*}{ Mean } \\
\hline & Fresh & 7 & 14 & \\
\hline $\mathbf{C}$ & $0.87 \pm 0.00$ & $0.85 \pm 0.01$ & $0.81 \pm 0.01$ & $0.84^{\mathrm{f}}$ \\
\hline P5 & $0.90 \pm 0.00$ & $0.98 \pm 0.01$ & $0.92 \pm 0.02$ & $0.93^{f}$ \\
\hline P10 & $1.15 \pm 0.00$ & $1.23 \pm 0.02$ & $1.11 \pm 0.01$ & $1.16^{\mathrm{e}}$ \\
\hline P15 & $1.46 \pm 0.01$ & $1.50 \pm 0.01$ & $1.31 \pm 0.02$ & $1.42^{\mathrm{d}}$ \\
\hline M5 & $0.90 \pm 0.01$ & $0.90 \pm 0.00$ & $0.88 \pm 0.01$ & $0.89^{f}$ \\
\hline M10 & $0.94 \pm 0.01$ & $0.94 \pm 0.01$ & $0.92 \pm 0.02$ & $0.93^{f}$ \\
\hline M15 & $1.15 \pm 0.01$ & $1.15 \pm 0.01$ & $1.10 \pm 0.01$ & $1.13^{\mathrm{e}}$ \\
\hline G5 & $3.61 \pm 0.06$ & $3.35 \pm 0.04$ & $3.02 \pm 0.03$ & $3.32^{\mathrm{c}}$ \\
\hline G10 & $6.11 \pm 0.12$ & $5.84 \pm 0.07$ & $5.46 \pm 0.08$ & $5.80^{b}$ \\
\hline G15 & $8.58 \pm 0.25$ & $8.18 \pm 0.32$ & $7.87 \pm 0.32$ & $8.20^{\mathrm{a}}$ \\
\hline Mean & $2.41^{\mathrm{a}}$ & $2.34^{\mathrm{a}}$ & $2.20^{b}$ & \\
\hline
\end{tabular}

C: control; P5: persimmon, 5\%; P10: persimmon, 10\%; P15: persimmon, 15\%; M5: mango, 5\%; M10: mango, 10\%; M15: mango, 15\%; G5: guava, 5\%; G10: guava, 10\% and G15: guava, $15 \%$. ${ }^{\text {a } V a l u e s ~ a r e ~ m e a n s ~} \pm$ standard deviations of triplicate determinations. Means in the same row with different superscript $(a, b, c \ldots)$ are significantly different $(p<0.05)$.

Table (7): Effect of adding fruit pulps on apparent viscosity (mPa.s) of yoghurt during storage period

\begin{tabular}{|c|c|c|c|c|}
\hline \multirow{2}{*}{ Treatments } & \multicolumn{3}{|c|}{ Storage period (days) } & \multirow{2}{*}{ Mean } \\
\hline & Fresh & 7 & 14 & \\
\hline $\mathbf{C}$ & $8452.00 \pm 90.00$ & $8245.00 \pm 52.00$ & $287.25 \pm 69.85$ & $5661.41^{\mathrm{f}}$ \\
\hline P5 & $9974.00 \pm 123.00$ & $8463.00 \pm 69.00$ & $216.5 \pm 12.30$ & $6295.66^{\text {ef }}$ \\
\hline P10 & $12473.00 \pm 1046.00$ & $11623.00 \pm 1123.00$ & $450.36 \pm 8.96$ & $8182.12^{\text {cde }}$ \\
\hline P15 & $12354.00 \pm 559.00$ & $8325.00 \pm 69.00$ & $394.57 \pm 12.17$ & $7024.52 \mathrm{def}$ \\
\hline M5 & $10352.00 \pm 84.89$ & $11699.00 \pm 20.07$ & $9176.33 \pm 48.29$ & $10409.11^{b}$ \\
\hline M10 & $10674.33 \pm 45.57$ & $11932.33 \pm 22.50$ & $9381.67 \pm 10.41$ & $10662.77^{\mathrm{b}}$ \\
\hline M15 & $12190.00 \pm 10.00$ & $14569.67 \pm 46.26$ & $11627.00 \pm 24.64$ & $12795.55^{\mathrm{a}}$ \\
\hline G5 & $9504.67 \pm 31.90$ & $10273.33 \pm 37.86$ & $8787.33 \pm 29.57$ & $9521.77^{b c}$ \\
\hline G10 & $9893.33 \pm 12.66$ & $10613.67 \pm 31.79$ & $8949.67 \pm 46.37$ & $9818.88^{b c}$ \\
\hline G15 & $10994.00 \pm 12.77$ & $11303.00 \pm 45.57$ & $8459.00 \pm 34.39$ & $10521.77^{b c}$ \\
\hline Mean & $10523.63^{\mathrm{a}}$ & $10574.69^{\mathrm{a}}$ & $6005.01^{b}$ & \\
\hline
\end{tabular}

C: control; P5: persimmon, 5\%; P10: persimmon, 10\%; P15: persimmon, 15\%; M5: mango, 5\%; M10: mango, 10\%; M15: mango,

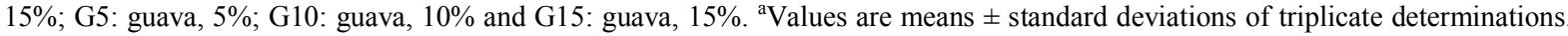
Means in the same row with different superscript $(a, b, c \ldots)$ are significantly different $(p<0.05)$.

\section{Total viable $\mathrm{LAB}$ count}

Addition of persimmon and mango pulps led to decrease of the total viable LAB count of yoghurt in all treatments, while, addition of guava pulp led to an increase in the total viable LAB count of yoghurt (Table $8)$. It was noticed that G10 (10\% guava pulp) had the highest $(\mathrm{p}<0.05)$ total viable LAB count than control and other treatments.

The total viable count of LAB for most fruit yoghurt treatments except P15 were increased up to 7 days and then decreased up to end of storage period. The effect of storage period was significantly $(p<0.05)$ for all fruit yoghurt treatments. Jin et al. (2018) reported that fruits and vegetables contains bioactive compounds can be used as substrates for the growth of probiotic bacteria.

\section{Organoleptic characteristics}

The overall acceptability of yoghurt fortified with M10, G5 and P10 were recorded the highest $(p<0.05)$ total acceptability score compared with other treatments. Addition of fruit pulps significantly at $(p<0.05)$ affected the total score values of all fruit yoghurt treatments (Table 9). Also, the storage period significantly $(\mathrm{p}<0.05)$ affected the overall acceptability. The score values of overall acceptability gradually decreased along the storage period. However, the yoghurt treatments containing $10 \%$ mango, 5\% guava and $10 \%$ persimmon pulp were quite good and gained the highest $(p<0.05)$ scores even after 14 days of storage period. 
Table (8): Effect of adding persimmon, mango and guava pulps on the total viable LAB count $\left(\log \mathrm{cfu}^{-1}\right)$ of yoghurt during storage period

\begin{tabular}{|c|c|c|c|c|}
\hline \multirow{2}{*}{ Treatments } & \multicolumn{3}{|c|}{ Storage period (days) } & \multirow{2}{*}{ Mean } \\
\hline & Fresh & 7 & 14 & \\
\hline $\mathrm{C}$ & $8.79 \pm 0.11$ & $9.16 \pm 0.19$ & $8.28 \pm 0.15$ & $8.74^{b}$ \\
\hline P5 & $8.12 \pm 0.08$ & $8.83 \pm 0.06$ & $7.45 \pm 0.65$ & $8.13^{d}$ \\
\hline P10 & $8.38 \pm 0.15$ & $8.89 \pm 0.05$ & $7.24 \pm 0.18$ & $8.17^{d}$ \\
\hline P15 & $7.95 \pm 0.05$ & $7.70 \pm 0.11$ & $7.09 \pm 0.13$ & $7.58^{\mathrm{e}}$ \\
\hline M5 & $8.53 \pm 0.22$ & $8.88 \pm 0.09$ & $8.03 \pm 0.06$ & $8.48^{\mathrm{c}}$ \\
\hline M10 & $8.55 \pm 0.22$ & $8.89 \pm 0.05$ & $8.47 \pm 0.25$ & $8.63^{b c}$ \\
\hline M15 & $7.95 \pm 0.05$ & $8.13 \pm 0.09$ & $7.14 \pm 0.05$ & $7.74^{\mathrm{e}}$ \\
\hline G5 & $8.77 \pm 0.02$ & $9.18 \pm 0.02$ & $8.29 \pm 0.05$ & $8.74^{b}$ \\
\hline G10 & $9.31 \pm 0.02$ & $9.41 \pm 0.01$ & $8.50 \pm 0.05$ & $9.07^{\mathrm{a}}$ \\
\hline G15 & $8.25 \pm 0.05$ & $8.47 \pm 0.02$ & $7.67 \pm 0.32$ & $8.13^{d}$ \\
\hline Mean & $8.50^{\mathrm{b}}$ & $8.75^{\mathrm{a}}$ & $7.79^{c}$ & \\
\hline
\end{tabular}

C: control; P5: persimmon, 5\%; P10: persimmon, 10\%; P15: persimmon, 15\%; M5: mango, 5\%; M10: mango, 10\%; M15: mango, 15\%; G5: guava, 5\%; G10: guava, $10 \%$ and G15: guava, $15 \%$. ${ }^{a}$ Values are means \pm standard deviations of triplicate determinations. Means in the same row with different superscript $(a, b, c .$.$) are significantly different (p<0.05)$.

Table (9): Organoleptic characteristics (overall acceptability) of fruit yoghurt during storage period

\begin{tabular}{|c|c|c|c|c|}
\hline \multirow{2}{*}{ Treatments } & \multicolumn{3}{|c|}{ Storage period (days) } & \multirow{2}{*}{ Mean } \\
\hline & Fresh & 7 & 14 & \\
\hline $\mathbf{C}$ & $80.33 \pm 2.08$ & $80.00 \pm 1.00$ & $81.67 \pm 1.15$ & $80.66^{\mathrm{g}}$ \\
\hline P5 & $85.33 \pm 1.15$ & $85.33 \pm 1.00$ & $85.33 \pm 1.15$ & $85.22^{\mathrm{de}}$ \\
\hline P10 & $92.33 \pm 2.08$ & $90.67 \pm 0.58$ & $91.00 \pm 1.00$ & $91.33^{b}$ \\
\hline P15 & $85.00 \pm 4.00$ & $82.67 \pm 0.58$ & $82.67 \pm 0.58$ & $83.44^{\mathrm{f}}$ \\
\hline M5 & $89.67 \pm 0.58$ & $90.00 \pm 1.00$ & $88.76 \pm 0.58$ & $89.44^{\mathrm{c}}$ \\
\hline M10 & $95.00 \pm 1.73$ & $95.33 \pm 0.58$ & $95.00 \pm 0.00$ & $95.11^{\mathrm{a}}$ \\
\hline M15 & $84.67 \pm 2.08$ & $84.33 \pm 0.58$ & $84.33 \pm 1.53$ & $84.55^{\text {ef }}$ \\
\hline G5 & $92.33 \pm 1.53$ & $92.33 \pm 2.08$ & $90.67 \pm 2.08$ & $91.77^{\mathrm{b}}$ \\
\hline G10 & $89.00 \pm 0.00$ & $87.67 \pm 1.15$ & $83.33 \pm 1.53$ & $86.66^{d}$ \\
\hline G15 & $73.33 \pm 1.53$ & $71.00 \pm 1.00$ & $69.33 \pm 3.21$ & $71.22^{h}$ \\
\hline Mean & $86.03^{\mathrm{a}}$ & $85.39^{a b}$ & $84.87^{b}$ & \\
\hline
\end{tabular}

C: control; P5: persimmon, 5\%; P10: persimmon, 10\%;P15: persimmon, 15\%;M5: mango, 5\%; M10: mango, 10\%;M15: mango, 15\%; G5: guava, 5\%; G10: guava, 10\% andG15: guava, 15\%. ${ }^{a}$ Values are means \pm standard deviations of triplicate determinations. Means in the same row with different superscript $(a, b, c \ldots)$ are significantly different $(p<0.05)$.

\section{CONCLUSION}

Persimmon, mango and guava pulps can be used successfully in making functional fruit yoghurt to give highest overall acceptability comparable with plain yoghurt especially flavour and texture \& body. The addition of $10 \%$ mango, $10 \%$ persimmon and $5 \%$ guava pulps give us the best treatments compared with other ratios. So, we can recommend enhancing flavour and radical scavenging activity of yoghurt by using these fruits for production of functional healthy yoghurt.

\section{REFERENCES}

Abbasi, A. M., F. Liu, X. Guo, X. Fu, T. Li and R. H. Liu (2017). Phytochemical composition, cellular antioxidant capacity and antiproliferative activity in mango (Mangifera indica L.) pulp and peel. International Journal of Food Science and Technology, 52: 817-826.

Abdeldaiem, A. M. and Kh. I. Blassy (2019). Effect of replacing skim milk powder by sweet lupine powder on characteristics of zebda-mango 
yoghurt drink. Ismailia Journal of Dairy Science and Technology Suez Canal University, 6: 9-17.

AOAC (2000). Official Methods of Analysis of AOAC International (Ed. Horwitz, W.), $17^{\text {th }}$ Ed., Suite 500, 481 North Fredric avenue Gaithersburg, Maryland, USA.

Arslan, S. and S. Bayrakci (2016). Physicochemical, functional, and sensory properties of yogurts containing persimmon. Turkish Journal of Agriculture and Forestry, 40: 68-74.

Arslan, S. and S. Ozel (2012). Some properties of stirred yoghurt made with processed grape seed powder, carrot juice or a mixture of grape seed powder and carrot juice. Milchwissenschaft, 67: 281-285.

Barros, L., L. Cabrita, M. V. Boas, A. M. Carvalho and I. C. F. R. Ferreira (2011). Chemical, biochemical and electrochemical assays to evaluate phytochemicals and antioxidant activity of wild plants. Food Chemistry, 127: 1600-1608.

Cakmakc1, S., B. Cetin, T. Turgut, M. Gurses and A. Erdoğan (2012). Probiotic properties, sensory qualities, and storage stability of probiotic banana yogurts. Turkish Journal of Veterinary and Animal Sciences, 36: 231-237.

Caleja, C., L. Barros, A. L. Antonio, M. Carocho, M. B. P. P. Oliveira, and I. C. F. R. Ferreira (2016). Fortification of yogurts with different antioxidant preservatives: a comparative study between natural and synthetic additives. Food Chemistry, 210: 262-268.

CoStat program (2005). Version 6.311. Copyright (1998-2005) CoHort Software, Monterey, California, USA.

Curi, P. N., B. S. Tavares, A. B. Almeida, R. Pio, M. Pasqual, P. M. Peche and V. R. Souza (2017). Characterization and influence of subtropical persimmon cultivars on juice and jelly characteristics. Anais da Academia Brasileira de Ciências, 89: 1205-1220.

El-Batawy, O. I., I. S. Ashoush and N. S. Mehanna (2014). Impact of mango and pomegranate peels supplementation on quality characteristics of yoghurt with or without whey powder. World Journal Dairy Food Science, 9: 57-65.

El-kholy, W. M. (2018). Preparation and properties of probiotic low fat frozen yoghurt supplemented with powdered doum (Hyphaene thebacia) fruit. Egption Journal of Dairy Science, 46: 6778.

Elliker, P. R., A. W. Anderson and G. Hannesson (1956). An agar culture medium for lactic acid streptococci and lactobacilli. Journal of Dairy Science, 39: 1611-1612.

Hegedusic, V., T. Lovric and A. Parmac (1993). Influence of phase transition (freezing and thawing) on thermophysical and rheological properties of apple puree-like products. Acta Alimentaria (Budapest), 22: 337-349.
IDF (International Dairy Federation) Standard 99 C (1997). Sensory evaluation of dairy products by scoring reference method.

Ismail, M. M., M. F. Hamad and E. M. Elraghy (2017). Rheological, Physicochemical, microbial and sensory properties of bio-rayebmilk fortified with guava pulp. International Journal of Food Science and Biotechnology, 1:9-20

Jin, X., W. Chen, H. Chen, W. Chen and Q. Zhong (2018). Comparative evaluation of the antioxidant capacities and organic acid and volatile contents of mango slurries fermented with six different probiotic microorganisms. Journal of Food Science, 83: 3059-3068.

Karaman, S., Ö. S. Toker, F. Yüksel, M. Çam, A. Kayacier and M. Dogan (2014). Physicochemical, bioactive, and sensory properties of persimmon-based ice cream: Technique for order preference by similarity to ideal solution to determine optimum concentration. Journal of Dairy Science, 97: 97-110.

Kavas, N. and G. Kavas (2016). Probiotic frozen yoghurt production using camel milk (Camelus dromedarius) with improved functions by strawberry guava (Psidium littorale var. cattleianum) fortification. Current Journal of Applied Science and Technology, 14: 1-12.

Khalil, R. A. M. (2013). The use of pomegranate juice as a natural source for antioxidant in making functional yoghurt drink. Egyptian Journal of Dairy Science, 41: 137-149.

Mahmood, A., N. Abbas and A. H. Gilani (2008). Quality of stirred buffalo milk yogurt blended with apple and banana fruits. Pakistan Journal Agricultural Sciences, 45: 275-279.

Manisha, W. H., R. Rajak and D. Jat (2017). Oxidative stress and antioxidants: an overview. International Journal of Advanced Research and Review, 2: 110-119.

Matter, A. A., A. M. Mahmoud and N. S. Zidan (2016). Fruit flavored yogurt: Chemical, functional and rheological properties. International Journal of Environmental and Agriculture Research, 2: 57-66.

McKinley, M. C. (2005). The nutrition and health benefits of yoghurt. International Journal Dairy Technology, 58: 1-12.

Moussa, M. E. M. and M. A. El-Gendy (2019). Physiochemical, microbiological and sensory properties of guava whey blend beverages. Middle East Journal of Applied Sciences, 9: 326-331.

Nunes, M. C. N., J. P. Emond, J. K. Brecht, S. Dea and E. Proulx (2007). Quality curves for mango fruit (cv. Tommy Atkins and Palmer) stored at chilling and nonchilling temperatures. Journal of Food Quality, 30: 104-120.

Parvez, G. M., U. Shakib, M. A. Khokon and M. Sanzia (2018). A short review on a nutritional fruit: guava. Open Access: Toxicology and Research, 1: 1-8. 
Raut, V., P. Sawant, D. Sawant and A. S. Ingole (2015). Studies on preparation of mango yoghurt drink. Asian Journal of Dairy and Food Research, 34: 13-17.

Ronak, P., A. H. Jana, M. Hiral and S. Balakrishnan (2016). Process standardization for the manufacture of mango flavoured steamed sweetened concentrated yoghurt (Bhapadahi). Journal of Dairy, Veterinary and Animal Research, 4: 293-303.

Sagdic, O., I. Ozturk, H. Cankurt and F. Tornuk (2012). Interaction between some phenolic compounds and probiotic bacterium in functional ice cream production. Food Bioprocess Technology, 5: 2964-2971.

Scibisz, I., M. Ziarno, M. Mitek and D. Zaręba (2012). Effect of probiotic cultures on the stability of anthocyanins in blueberry yoghurts. LWTFood Science Technology, 49: 208-212.

Souza, J. M. A., S. Leonel, J. H. Modesto, R. A. Ferraz and B. H. L. Gonçalves (2018). Fruit physicochemical and antioxidant analysis of mango cultivars under subtropical conditions of Brazil. Journal of Agricultural Science and Technology, 20: 321-331.

Tanwar, B., B. Andallu and S. Chandel (2014). Influence of processing on physicochemical and nutritional composition of Psidium guajava L. (Guava) products. International Journal of Agriculture and Food Science Technology, 5: 47-54.

Vahedi, N., M. M. Tehrani and F. Shahidi (2008). Optimizing of fruit yoghurt formulation and evaluating its quality during storage. American-Eurasian Journal Agriculture and Environmental Science, 3: 922-927.

Vazquez-Olivo, G., M. Antunes-Ricardo, J. A. Gutiérrez-Uribe, T. Osuna-Enciso, J. LeónFélix and J. B. Heredia (2019). Cellular antioxidant activity and in vitro intestinal permeability of phenolic compounds from four varieties of mango bark (Mangifera indica L.). Journal of the Science of Food and Agriculture, 99: 3481-3489.

Yaqub, S., U. Farooq, A. Shafi, K. Akram, M. A. Murtaza, T. Kausar and F. Siddique (2016). Chemistry and functionality of bioactive compounds present in persimmon. Journal of Chemistry, 2016: 1-13.

Ziena, H. M. and A. M. Abd-Elhamid (2009). Production of functional yogurt: effect of natural antioxidant from guava (Psidium guajava) leaf extract. Journal of Agriculture and Food Science Technology, Alexandria University Egypt, 8: 102-116.

\section{الخصائص الوظيفية للزبادي المدعم بلب الفواكه

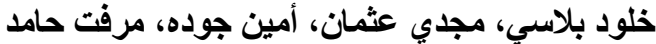

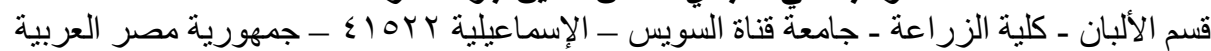

الزبادي أحد الألبان المتخمرة الناتجة من تخمر سكر اللاكتوز الموجود باللبن ببكتريا حمض اللاكتيك. هنالك اتجاه لتدعيم الزبادي

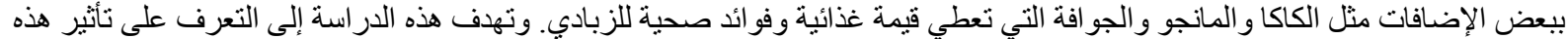

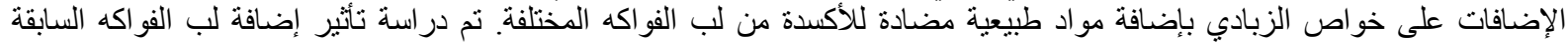

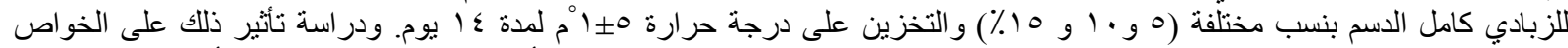

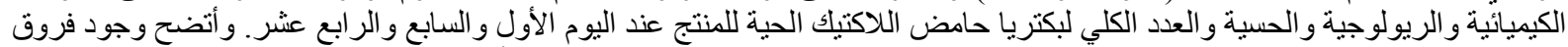

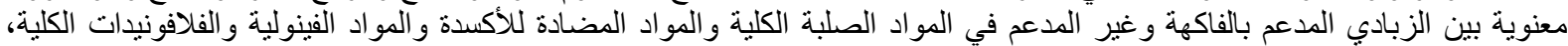

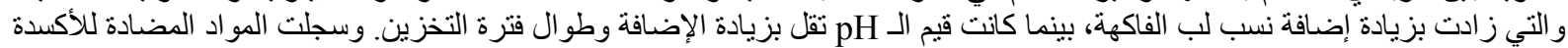

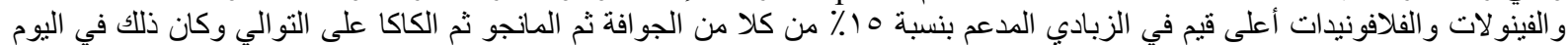

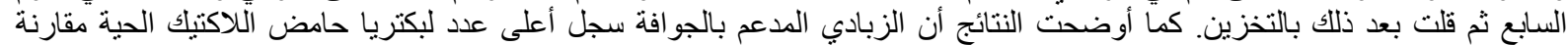

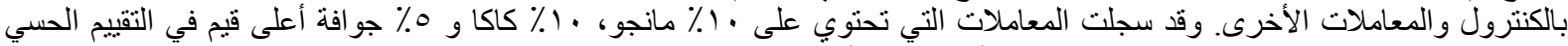

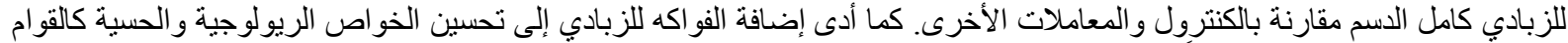
و النكهة مقارنة بالكنترول بالإضافةً إلى تدعيم الزبادي بالعديد من الإيد المركبات الحيوية. 